\title{
İdeolojik Bağlam: 1920’li Yıllarda Sovyet Konut Mimarisi ve Narkomfin Komünal Konutu
}

\author{
Sevim ATEŞ CAN ${ }^{1} 1$, Kadir Emre BAKIR ${ }^{D} 2^{*}$ \\ ${ }^{1}$ Burdur Mehmet Akif Ersoy Üniversitesi, Mühendislik Mimarlık Fakültesi, Burdur \\ ${ }^{2}$ Burdur Mehmet Akif Ersoy Üniversitesi, Fen Bilimleri Enstitüsü, Burdur \\ Geliş Tarihi (Received): 23.04.2021, Kabul Tarihi (Accepted): 10.06.2021 \\ $\square$ Sorumlu Yazar (Corresponding author $\left.{ }^{\star}\right)$ : kemrebakir@gmail.com \\ (c) +902482132783 등 +902482132704
}

ÖZ

Çalışmada, ideolojik bağlam ve konut planlaması ilişkisi 1920'lerde Sovyetler Birliği'ndeki konut mimarisinin ideolojiyi desteklemesi üzerinden ele alınmaktadır. Ekim Devrimi ve I. Dünya Savaşı sonrasında yaşanan ekonomik zorlukların yanı sıra teknolojik eksiklikler, kadınların işgücüne katıımının sağlanması konut mimarisi kapsamında birçok mimarın ele aldığı çözümleri etkilemiştir. Bu sorunlara çözüm önermek için 1926'da mimari tasarım yarışması düzenlenmiştir. Bu tasarımların çoğunda anaokulları, kütüphaneler, ortak mutfaklar, ortak yeme- içme mekânları gibi ortak alanlar vurgulanmıştır. Narkomfin Komünal Konutu, 1928 yılında Moskova'da Finans Bakanlığı bürokratları için tasarlanmıştır. Narkomfin Komünal Konutu kullanıcıları günlük yaşamlarında yemek yemek, kitap okumak, egzersiz yapmak vb. için ortak alanlara yönlendirilmiştir. Narkomfin Komünal Konutu'nda F tipi konut birimleri komünal hayata geçiş birimi olarak düşünülmüştür. Ancak, zaman içinde $\mathrm{F}$ tipi konut birimlerine olan talebin artacağı ve $\mathrm{K}$ tipi konut birimlerinin azalacağı varsayımı gerçekleşmemiştir. Bu çalışmada, ideolojik bağlamın konut planlamasına getirdiği yeni tanım örnekler üzerinden irdelenmektedir.

Anahtar Kelimeler: İdeolojik bağlam, konut mimarisi, Narkomfin Komünal Konutu, Sovyet konut politikası

\section{Ideological Context: Soviet Residential Architecture in the 1920s and Narkomfin Communal House}

\begin{abstract}
In this study, the relationship between ideological context and residential planning is examined through the ideology in the Soviet Union in the 1920s being supported by the residential architecture. Besides economic difficulties experienced after the October Revolution and World War I, the topics like technological deficiencies and encouraging women's labor force participation affected the solutions addressed by many architects within the scope of residential architecture. To offer a solution for these problems, the architectural design competition was held in 1926. In most of these designs, spaces such as kindergartens, libraries, common kitchens, common dining rooms, etc. were emphasized as common places. The Narkomfin Communal House was designed for bureaucrats of the Russian Ministry of Finance in Moscow in 1928. The residents of the Narkomfin Communal House were led to common spaces in their daily life for eating, reading, doing exercises, etc. F-type apartments in Narkomfin Communal House were thought as transitional type to communal life. However, the assumption that the demand for F-type apartments would increase and the demand for K-type apartments would decrease over time did not realise. In this study, the new definition that was brought to residential planning by ideological context is examined within instances.
\end{abstract}

Keywords: Ideological context, residential architecture, Narkomfin Communal House, Soviet residential policy 


\section{GíRiş}

Çalışma, ideolojik bağlamın konut mimarisine etkisini 1920 'li yıllarda Sovyet Rusya'da ortaya konmuş olan "komünal konut" kavramıyla ele almaktadır. Ekim Devrimi ile konut politikalarının değişimi, bu politikalar ışığında toplumsal değişimde, dönüşümde hedeflenen başlıklar ve öngörülemeyen koşullar da çalışma kapsamında ifade edilmektedir. Dönemin mimarlarının bireysel girişimleri ve sonrasında bu mimarların devlet destekli çalışmaları komünal konutun ortaya çıkışında etkili olan faktörlerdir. Komünal konutun toplumu ideolojik olarak yönlendirme amacı gütmesi ile birlikte Sovyetler dışında inşa edilmiş yapı örneklerinden biri olan, Le Corbusier tarafından tasarlanan Unité d'Habitation ile benzerlik göstermesi ilgi çekicidir. Öyle ki, Narkomfin Konutu'nun inşa sürecini gözlemlemiş olan Le Corbusier'nin Unité d'Habitation tasarımında Narkomfin Komünal Konutu'ndan etkilendiği ifade edilmektedir (Sherwood, 1981). Bu açıdan inşa edilmiş komünal konut örneği olan Narkomfin Komünal Konutu çalışmada odaklanılan ana örnektir.

\section{Sovyet Konut Politikaları ve Komünal Konut Kav- ramı}

Ekim 1917 Devrimi ile birlikte birçok alanda olduğu gibi özel mülkün kamulaştırıması konutlar için de geçerli olmuştur. Konutların kamulaştırılması temelinde diğer politikalar; aşırı nüfus yoğunluğunu engellemek için konut alanlarının dağılımının yeniden ele alınması, kiraların geçici süreyle kaldırılması, konutların yerel idarelere devri, oluşturulan konut kooperatifleriyle mevcut konut stokunun yönetimi olarak ifade edilmektedir. 1921-1928 yılları arasında uygulanan Yeni Ekonomi Politikası'nın getirilerinden olan, kırsal nüfusun kentlere göçü ile birlikte I. Dünya Savaşı ve Ekim Devrimi'nin neden olduğu ekonomik sorunlar ve teknolojik yetersizlikler konut politikalarının biçimlenmesinde rol oynamıştır. Öte yandan toplumsal anlamda gündelik hayatın yönlendirilmesi açısından Sovyetler Birliği'nin II. Dünya Savaşı öncesinde, Devrim'den 1941 yılına kadar uyguladığı konut politikalarının temelinde ise kadın- erkek eşitliğinin olduğu belirtilmektedir. Bu eşitlik "kadının ev işlerinden ve çocuk bakımından kurtarılarak iş gücüne katılımının sağlanması" olarak ifade edilmektedir (Andrusz, 1990; Vega, 2020).

Her ne kadar konut sorunu toplumun her kesimi için çözülmeyi beklese de belirli konfor şartlarını sağlayabilecek konutlar başlangıçta kamu ve askeri personelin barınması için inşa edilmiştir. Sovyet hükümetinin Yeni Ekonomi Politikası kapsamında işçilerin barınabileceği, kitlesel üretime uygun konutlar için öneri yer almamıştır. Öte yandan, 1928 yılında uygulanan I. Beş
Yıllık Plan kapsamında köylülerin endüstri tesislerinde çalışması için getirilmesi, işçilerin yerleşkelerde barınma sorunlarını da beraberinde getirmiştir. I. Beş Yıllık Plan'ın resmi sonuçlarına göre kırsaldan kente göç nedeniyle kent nüfusu 13,9 milyon kişi artarken, bu süreçte her bir yeni kent sakini için $2 \mathrm{~m} 2$ olmak üzere 27 milyon $\mathrm{m} 2$ konut inşa edilmiştir. Belirtilen barınma sorunları ucuza mal edilebilecek ve kitlesel üretimi sağlanabilecek konut tasarımları için arayışları da beraberinde getirmiştir (Khmelnitsky, 2016).

Konut politikaları kapsamında ele alınan sorunlara çözüm bulma isteği ve toplumun ideolojik inşası için yola çıkan dönem mimarları, Moisei Ginzburg'un başını çektiği 1925-1930'lu yıllarda aktif olan Modern Mimarlar Birliği (OSA) bünyesinde çalışmalar yapmıştır. Bu noktada, yapılan çalışmaların tamamen ideolojik açıdan soyutlanarak yapılmadığı, dünyada konut tasarımının ele alınışı ve tasarımların uygulanmasının da incelendiği ifade edilmektedir. Ancak evrensel çözümlerin ideolojiyle yorumlanarak toplumu dönüştürmesi, uygulama açısından da yerel sorunlara cevap niteliğinde (teknolojik, ekonomik yetersizlikler vb.) olması hedeflenmiştir. Modern Mimarlar Birliği (OSA)'nin Avrupa'da 1928 yılında kurulmuş olan CIAM (Congrès internationaux d'architecture moderne- Uluslararası Modern Mimarlık Kongresi) ile benzerlik gösterdiği ve konut, barınma gibi evrensel sorunlara yerel ve ideolojik çözümler konusunda ise farklılık gösterdiği ifade edilmektedir. Hatta OSA'da yer alan mimarlardan Nikolay Kolli'nin aynı zamanda CIAM üyesi olduğu belirtilmektedir. Modern Mimarlar Birliği (OSA)'nin çalışmaları, kendi yayın organı olan dergi, SA (Sovremennaya arkhitektura)'da yayınlanmıştır. Dergide Le Corbusier, Geritt Rietveld, Frank Lloyd Wright, Walter Gropius gibi isimlerin de tasarımları yer almıştır (Khmelnitsky, 2016). 1926 yılında Modern Mimarlar Birliği (OSA), işçiler için konut tasarımı yarışması ilan etmiştir. Bu yarışmanın temel amacı; işçiler için konut intiyacının karşılanması ile birlikte sosyalist ailenin tanımını yapmak, bireysel- kolektif yaşamın ilişkisini açıklamak olarak ifade edilmiştir. Yarışma ile ortaya konan tasarımlar Modern Mimarlar Birliği (OSA)'nin dergisi SA'da yayınlanmıştır (URL-1, 2015). Şekil 1'de yarışma sonucu ortaya konan tasarımların yayınlandığı SA dergisinin kapağı verilmiş̧tir. 


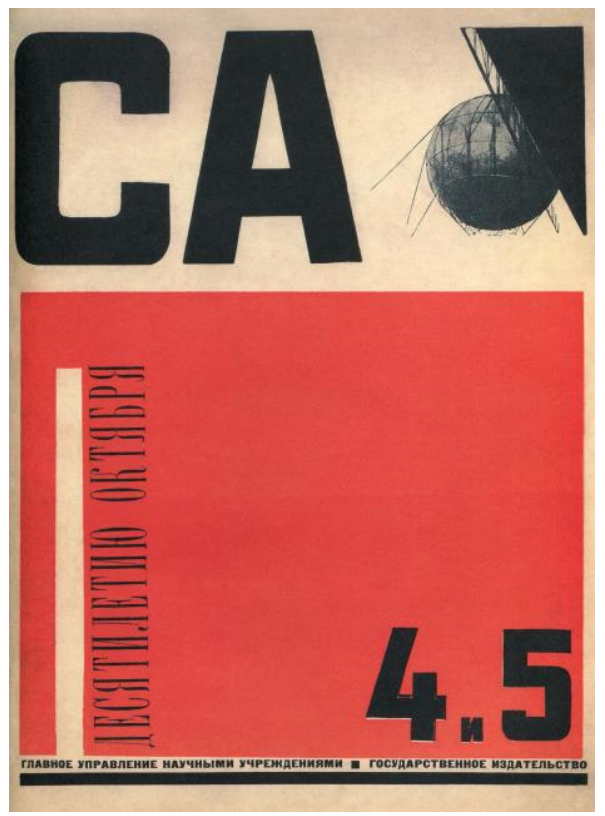

Şekil 1. Yarışma sonucu ortaya konan tasarımların yayınlandığı SA dergisinin kapağı (URL-1, 2015)

Yarışma sonucunda tekil yapılarla birlikte konut kompleksi olarak ifade edilebilecek birkaç yapıdan oluşan tasarımlar da ortaya konmuştur. Tüm tasarımlarda ortak olan noktalardan biri, barınma birimlerinde tuvalet ve mutfak mekânlarının yer alması şeklinde ifade edilmektedir. Kolektif yaşamı işaret eden birimler olan ortak mutfaklar, yeme- içme birimleri, kütüphaneler, okuma salonları, atölyeler, çamaşırhaneler, kreşler ve anaokulları bu tasarımlarda yer alan diğer mekânlardır. Bu mekânlar farklı tasarımlarda farklı konumlarda çözülmüş; Vladimirov ve Pasternak'ın tasarımında ortak birimler konut birimlerinin altında konumlandırılmıştır. Ginzburg ve Vegman'ın tasarımlarında; üst katlarında ortak yeme- içme birimleri, alt katlarında ise çocukların eğitimi ve bakımı için ayrılan birimler barındıran yapı, konut birimlerinin bulunduğu yapıdan ayrı olacak şekilde yer almıştır. Konutlar ve ortak birimler arasında bağlantılar kurularak bütünsellik sağlanmaya çalışıımıştır. Öte yandan, ortak birimlerle ve konut yapılarının birbirinden ayrı şekilde tasarlandığı yapılar da OI, Sobolev, Vorotytseva ve Polyak tarafından ortaya konulmuştur. Şekil 2'de yarışma sonucunda elde edilen konut tasarımları ve mimarları verilmiştir. Tasarımlarda servis alanlarının kapladığı alan azaltılmaya çaIışıImış, böylelikle simetrik çözümler ortaya konmuştur. Şekil 3'te tasarımların yaşama birimlerine ait planları, görselleri ve mimarları verilmiştir (Vega, 2020).

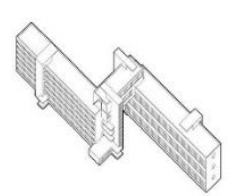

Ginzburg

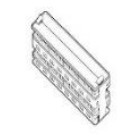

Vorotyntseva

ve

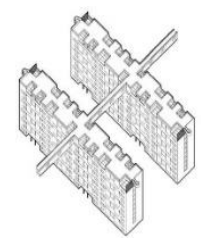

Vegman

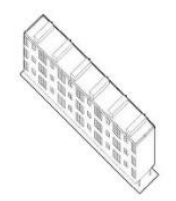

Nikolsky
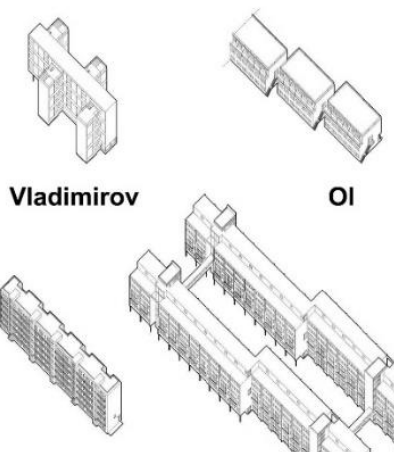

Pasternak
OI

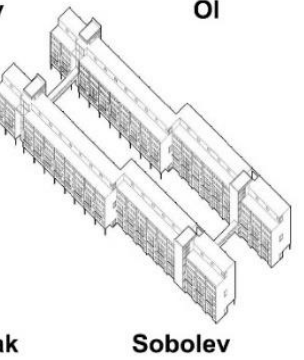

Şekil 2. Yarışma sonucunda elde edilen konut tasarımları ve mimarları (Vega, 2020) 


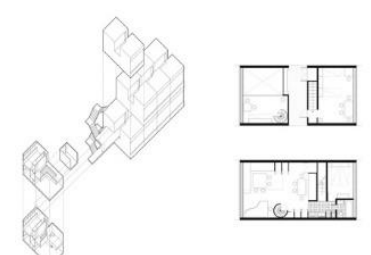

Ginzburg

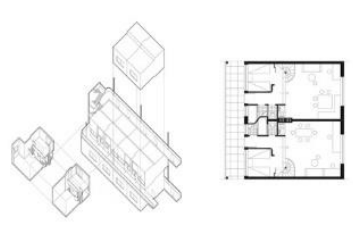

Vorotyntseva ve Polyak

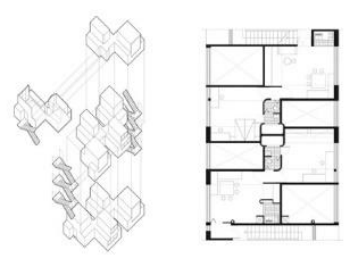

Vegman

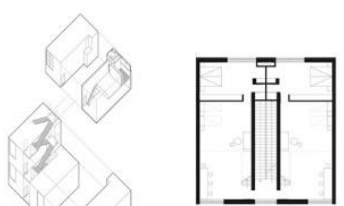

Nikolsky

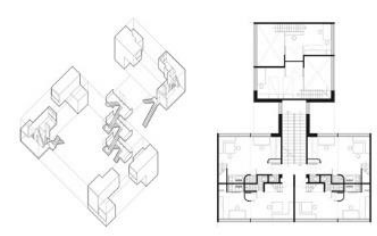

Vladimirov

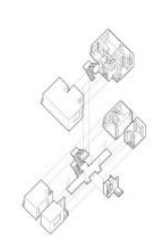

Pasternak

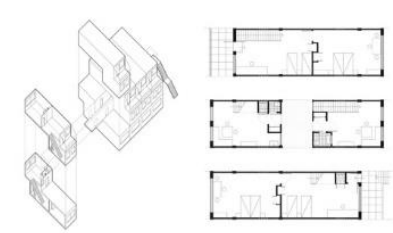

OI
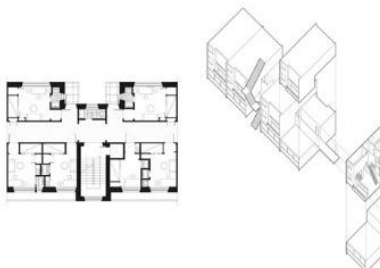

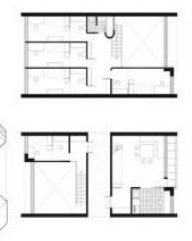

Sobolev

Şekil 3. Tasarımların yaşam birimlerine ait planları, görselleri ve mimarları (Vega, 2020)

Yarışmanın ardından Sovyetler Birliği'nde Standardizasyon Kurumu tarafından konutların tipleştirilmesi ve standardizasyonu için bir birim kurulmuştur. Bu birimde Modern Mimarlar Birliği (OSA) mimarları görev almıştır. Bu birimin temel amacı; yarışma ile elde edilen tasarımların matematiksel hesaplarla standardize edilmesi, ekonomik hale getirilmesi olarak ifade edilmektedir. Bu doğrultuda mekân optimizasyonu üzerinde çalışıımış, alan kullanımı bakımından merdiven etrafında örgütlenen birimleri içeren tasarımların diğer tasarımlara göre daha etkin olduğu ortaya konmuştur. Mekânların kullanımda konfor şartlarını minimum alanda sağlamak için, Le Corbusier, Gropius gibi diğer çağdaş mimarların da yaptığı gibi zaman- hareket çalışmaları gerçekleştirilmiş ve servis mêkanları modernize edilmeye çalışılmıştır. Tüm bu çaIışmalar Stroikom birimi altında gerçekleştirilmiştir (Guillén, 2008; Vega, 2020).
Stroikom bünyesinde Barshch ve Vladimirov'un 1929 yılında ortaya koymuş olduğu tasarım; yaşama birimleri, yemek salonu, çalışma salonu, kütüphane, revir, sınıf, spor salonu barındırması bakımından "küçük bir şehir" olarak nitelenmektedir. Böylelikle konut kompleksini ifade eden komünal konut kavramı Dom Kommuna ortaya çıkmıştır (Teige, 2002). Şekil 4'te Barshch ve Vladimirov tarafından 1929 yılında ortaya konmuş komünal konut kompleksine ait görsel verilmiştir. Dinlenme salonu ve yemek salonu gibi ortak birimlerde galerili çözümler iç mekâna zenginlik katmayı amaçlamış ve kullanıcılarının görsel iletişim kurmasına imkân sağlamıştır. Şekil 5'te Barshch ve Vladimirov tarafından tasarlanan konut kompleksinin dinlenme ve yemek salonlarına ait görseller verilmiştir. 


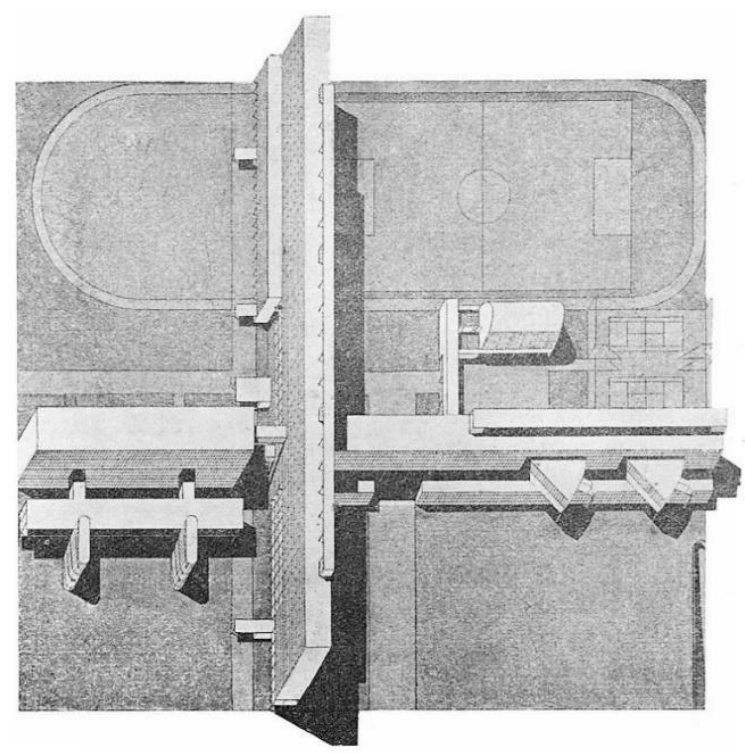

Şekil 4. Barshch ve Vladimirov tarafından 1929 yılında ortaya konmuş komünal konut kompleksine ait görsel (Teige, 2002)

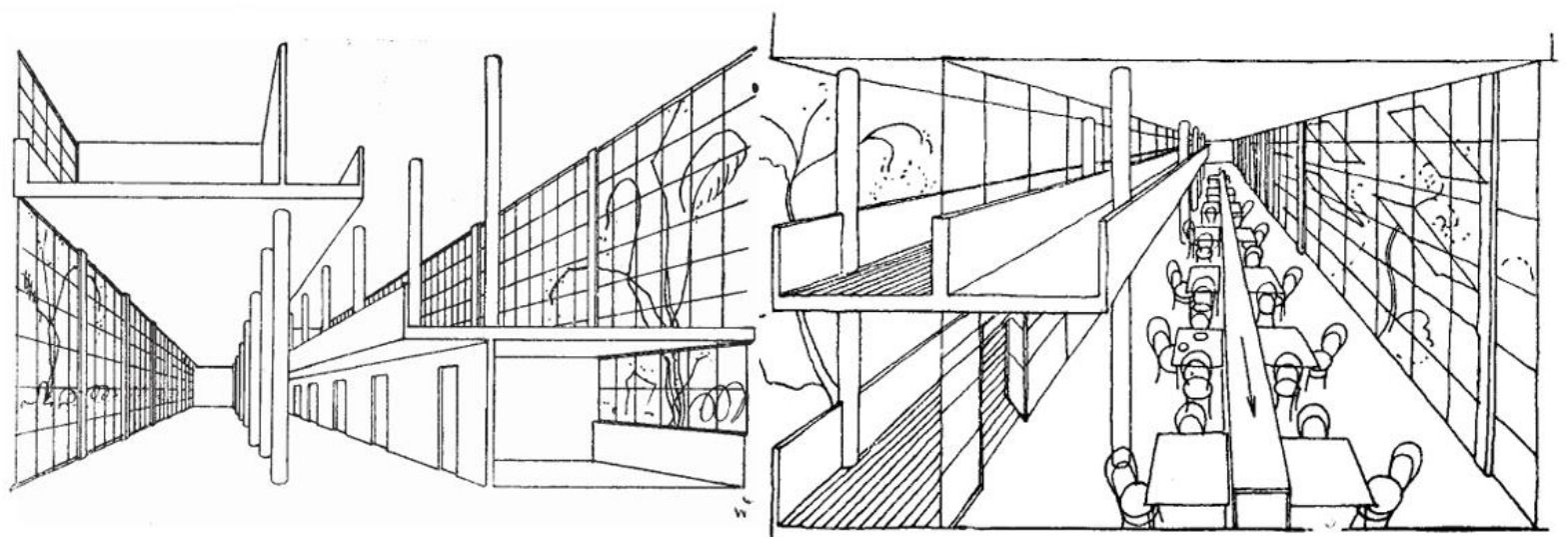

Şekil 5. Barshch ve Vladimirov tarafından tasarlanan konut kompleksinin dinlenme ve yemek salonlarına ait görseller (Teige, 2002)

Barshch ve Vladimirov'un tasarımında yer alan ve sadece bir kişi için tasarlanan yaşama birimleri $1,6 \mathrm{~m} \mathrm{x}$ $3,75 \mathrm{~m}$ ölçülerindedir. Yaşama biriminin minimum düzeyde tutularak kullanıcıların ortak birimlere yönlendirilmesi ortak yaşamın güçlendirilmesi amaçlanmaktadır. Böylece kullanıcıların sadece uyumak, dinlenmek, kişi- sel hijyen eylemleri için bu yaşama birimlerini kullanacağı, diğer tüm gündelik aktivitelerin ortak mekânlarda gerçekleştirileceği öngörülmüştür. Bu durum, mimarlığın ideolojik bağlamda araç olarak kullanılmaya çalışılması yöntemine açık bir örnektir. Şekil 6'da Barshch ve Vladimirov tarafından tasarlanan konut kompleksine ait yaşama biriminin görseli verilmiştir. 


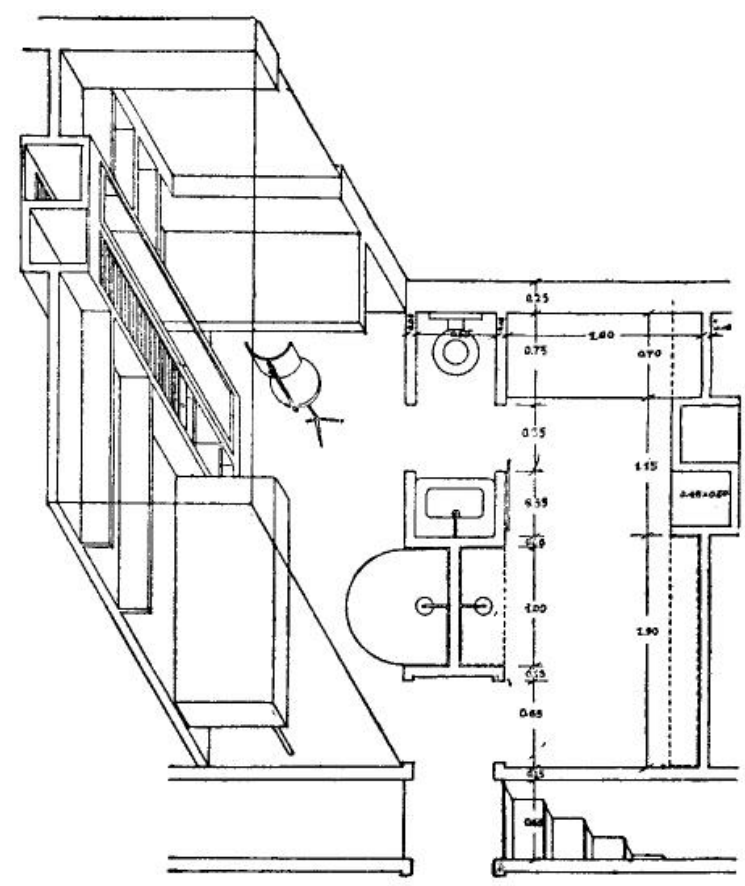

Şekil 6. Barshch ve Vladimirov tarafından tasarlanan konut kompleksine ait yaşama biriminin görseli (Teige, 2002)

Stroikom bünyesinde Barshch, Vladimirov ile birlikte Pasternak ve Ginzburg tarafından da plan tipleri geliştirilmiş, analiz edilmiş ve bu plan tiplerinin ekonomik verimlilikleri tablo haline getirilmiştir. Yapılan analizler sonucunda $\mathrm{F}$ tipi olarak adlandırılan plan tipinin diğer plan tipleri arasında hem ekonomik hem de mimari açıdan daha verimli olduğu ortaya konulmuştur. Şekil 7'de ortaya konan plan tiplerinin ekonomik verimlilikleri grafiği verilmiştir. F tipi planda ara kotlu çözümlerle hacimsel anlamda optimizasyon sağlanmış, mutfak çözümleri mümkün mertebe küçük tutularak, kullanıcılar ortak mutfak ve yeme- içme mekânlarına yönlendirilmiştir. Bir bakıma F tipi yaşama birimlerinin yer aldığı konut tasarımlarıyla gündelik hayatta komünal yaşama "hızı" bir geçiş yapılması amaçlanmıştır. Narkomfin Komünal Konutu bu faktörlerin dikkate alınarak inşa edildiği önemli bir örnektir (Buchli, 1998; Vega, 2020). 


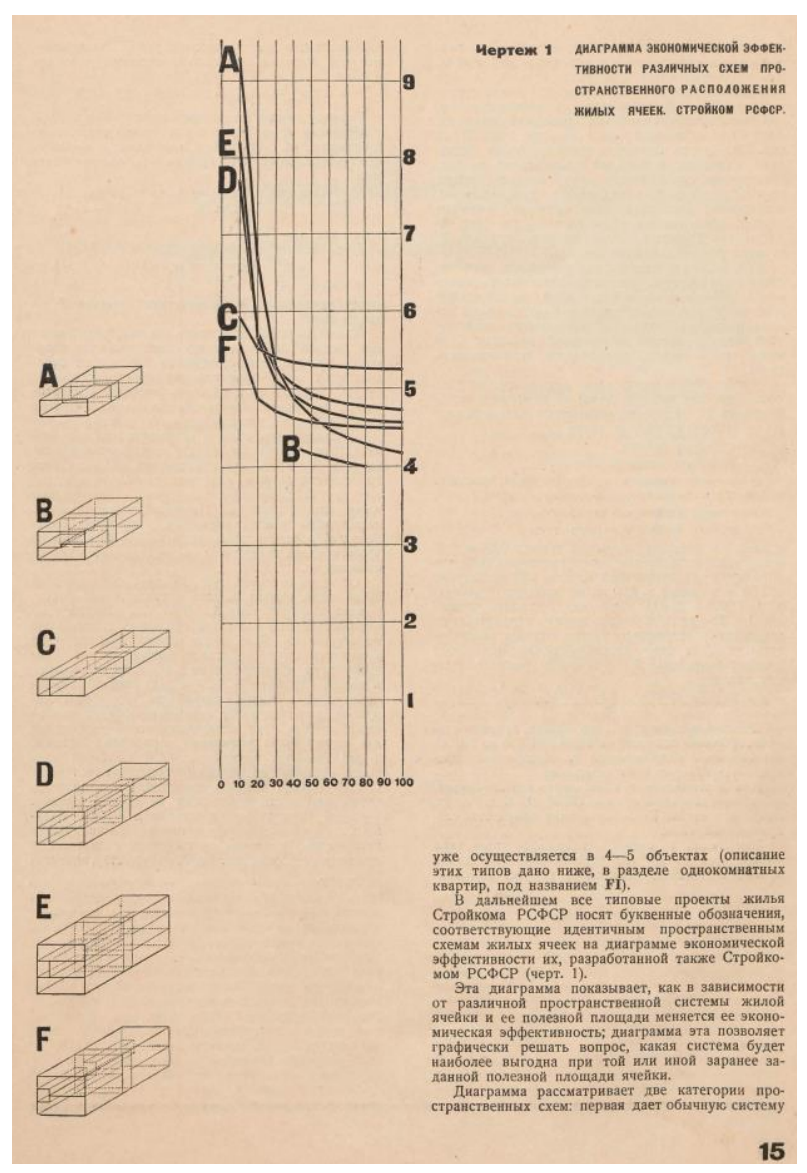

Şekil 7. Ortaya konan plan tiplerinin ekonomik verimlilikleri grafiği (Vega, 2020)

\section{Narkomfin Komünal Konutu}

Narkomfin Komünal Konutu 1928-1929 yılları arasında Moskova'da Novinksy Bulvarı'nda inşa edilmiştir. Finans Bakanlığı çalışanları için tasarlanmış konut yapısının mimarları Moisei Ginzburg ve İgnatii Milinis'tir. Sayıca yaklaşık 50 ailenin (200 kişi) yaşaması için tasarlanan yapı grubunun tasarım çalışmalarında, yerleşim planı üzerinde yaşama birimlerinin bulunduğu blok ve komünal blokun yanı sıra dairesel planlı kreşe ve çamaşırhaneye yer verilmiş, bu yapılardan kreş haricinde hepsi inşa edilmiştir. Yaşama bloku komünal bloka köprüyle bağlanmaktadır (Arıtan, 2004). 15 Mayıs 1933 tarihli öneri yerleşim planında, 6 Ağustos 1929 tarihli öneri yerleşim planında yer verilen çamaşırhanenin yaşama blokuna paralel şekilde uzatıldığı, dairesel planlı kreşin bu planda yer almadığı görülmektedir. Ayrıca ikinci etap için komünal blokun yakınında üst düzey Sovyet yetkililerinin barınması için Stalinist tarzda inşa edilmiş yapıya yer verilmiştir (Buchli, 1998). Şekil 8'de 6 Ağustos 1929 ve 15
Mayıs 1933 yıllarında hazırlanmış öneri yerleşim planları verilmiştir.

Kütlesel anlamda Narkomfin Komünal Konutu'nun biçimlenişine bakıldığında Le Corbusier'nin ortaya koymuş olduğu, yapının pilotiler üzerine kaldırılması, bant pencereler, serbest plan gibi başlıklar Narkomfin Komünal Konutu'nda açıkça görülebilmektedir. Le Corbusier'nin Narkomfin Komünal Konutu'ndan etkilenerek Unité d'Habitation tasarımını ortaya koyduğu ifade edilmektedir (Sherwood, 1981). Bu durum, konut tasarımında evrensel açıdan karşılıklı fikir alışverişinin sağlanabildiğinin (CIAM-OSA arasında) ve ideolojik anlamda farklılıkların bu etkileşimi etkilemediğinin veya engellemediğinin göstergesidir. Şekil 9'da Narkomfin Komünal Konutu'nun restorasyon öncesi ve restorasyon çalışmasının ardından kavuştuğu günümüzdeki hali verilmiştir. 

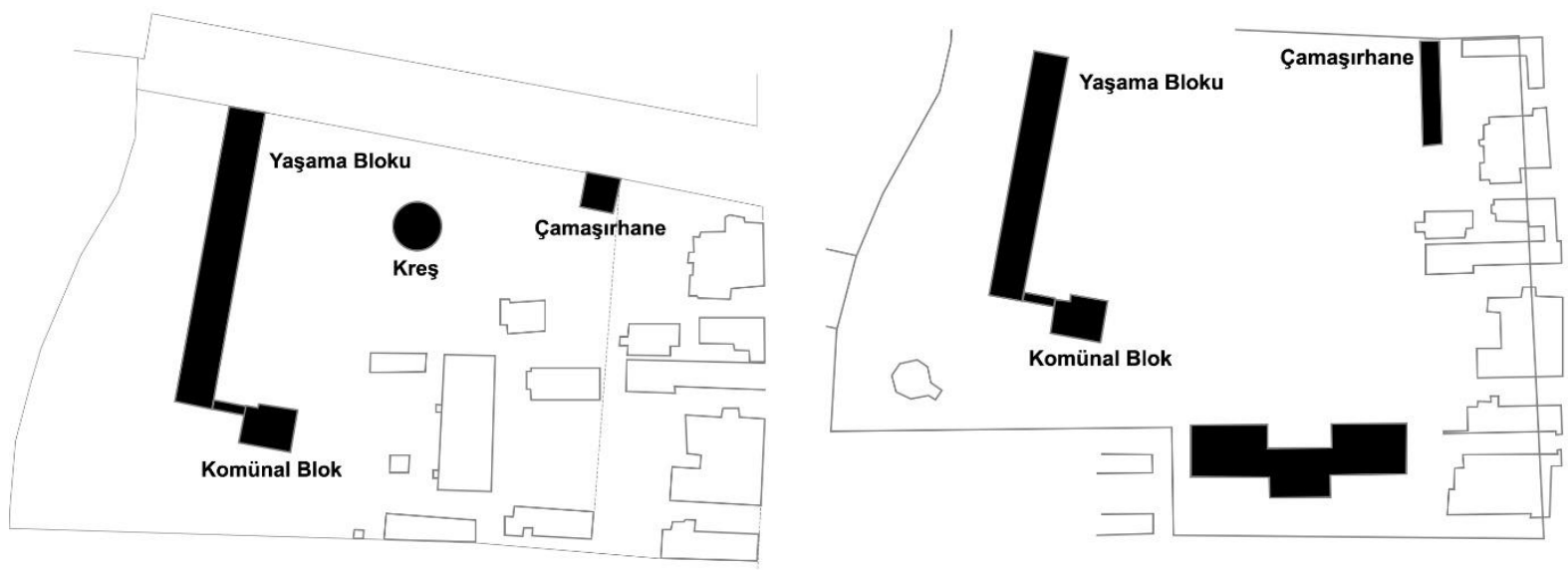

Şekil 8. Narkomfin Komünal Konutu'nun 6 Ağustos 1929 tarihli (solda) ve 15 Mayıs 1933 tarihli öneri yerleşim planı (sağda) (Buchli, 1998)
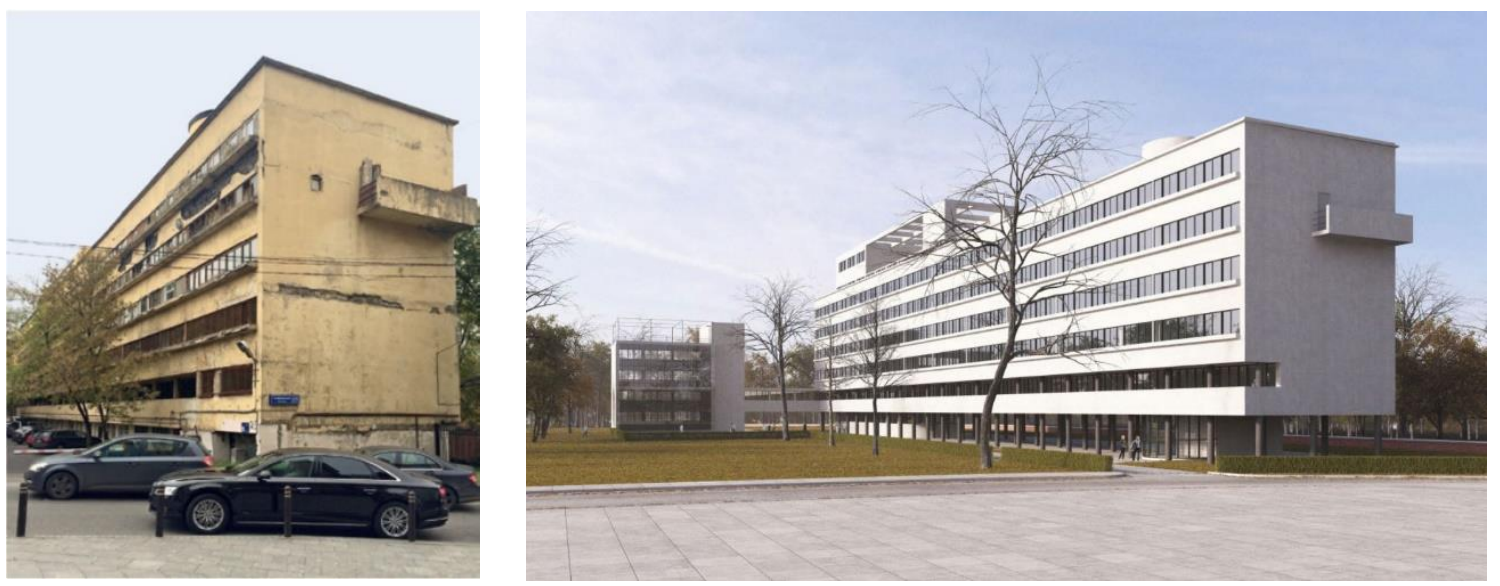

Şekil 9. Narkomfin Komünal Konutu'nun restorasyonu öncesi (solda) (Ginzburg ve Starostina, 2020b) ve sonrasındaki hali (sağda) (URL-2, 2020)

Ara kotlu çözümler, yaşama blokunun yatay ve düşey sirkülasyonunun biçimlenmesinde etkili olmuştur. Yaşama blokunun iki ucunda bulunan merdivenlerle tüm katlara erişim sağlanabilmektedir. Öte yandan birinci katta yer alan koridorla $\mathrm{K}$ tipi konutlara ve komünal birime ulaşılabilmekte, dördüncü katta yer alan koridorla da F tipi konutlara ulaşılmaktadır. Bu nedenle belirtilen katlarda yer alan koridorların haricinde koridor bulunmamaktadır. Şekil 10'da Narkomfin Komünal Konutu'nun düşey ve yatay sirkülasyon şeması verilmiştir.

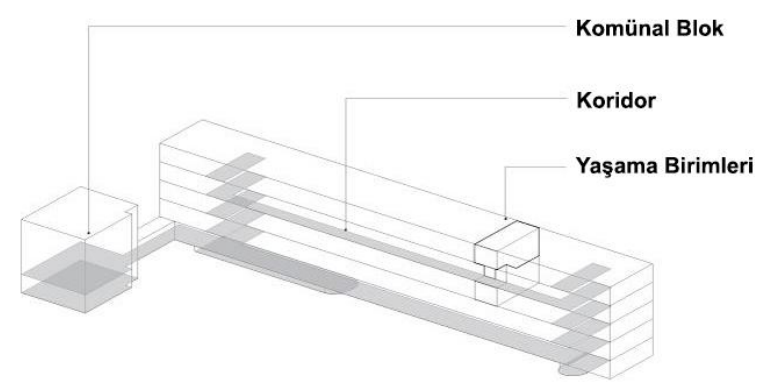

Şekil 10. Narkomfin Komünal Konutu'nun düşey ve yatay sirkülasyon şeması (URL-3, 2012) 
K tipi plana sahip konutların çocuk odası ve ayrı mutfağı bulunması aileler için inşa edildiğini göstermektedir. $F$ tipi plana sahip konut birimlerinde ise ayrı bir mutfak mekânı yerine mutfak nişi bulunmaktadır. Bekârlar ve çocuksuz aileler için tasarlanmış olduğu ifade edilen $F$ tipi plana sahip konut birimleri komünal yaşamın simgesi olarak yorumlanabilmektedir. 2-F tipi konutlar az sayıda olup merdivenlerin etrafında yer almaktadır. Şekil 11'de $\mathrm{F}, 2-\mathrm{F}$ ve $\mathrm{K}$ tipi birimlere ait plan şemaları ve yaşama blokunun kesit şeması verilmiştir. Stroikom bünyesinde yapılan çalışmalarla geliştirilmiş plan tiplerinden $F, 2 F$ ve $\mathrm{K}$ tipi plana sahip birimlerle yaşama bloku oluşturulmuştur. Yaşama blokunda 32 adet $F$ tipi birime yer verilmiştir. F tipi birimlerde; küçük bir holden 3.60 m yüksekliğinde yaşama mekânına geçiş sağlanmaktadır. Diğer kısımda tavana kadar olan yükseklik 2.30 m'ye düşmektedir. Bu kısımda yatak odası ve banyo bulunmaktadır. 2-F tipi birimler merdiven çevresinde yer almakta olup, birimlere merdiven boşluğundan girilmektedir. Hacimce iki adet $F$ tipi birimin yan yana getirilmesiyle oluşturulan $2 \mathrm{~F}$ tipi birimde giriş holü, banyo, mutfak ve yemek odasının yüksekliği tavana kadar 2.30 m iken, iki yaşama mekânında bu yükseklik 3.60 m'ye çıkmaktadır. Tip olarak belirlenen bu yaşama birimlerinin yanında yapıda tasarıma sonradan ilave edilen mimar Nikolay Milyutin için inşa edilmiş çatı katı dairesi bulunmaktadır (Ginzburg ve Starostina, 2020a; Kazus, 2020).
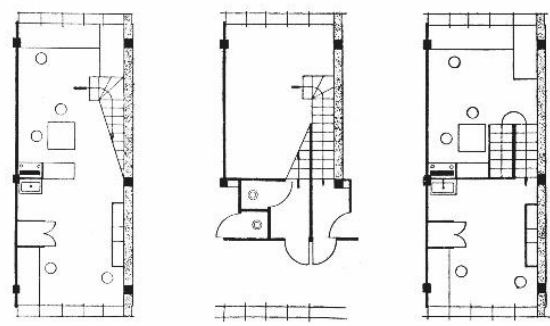

F tipi birime ait planlar
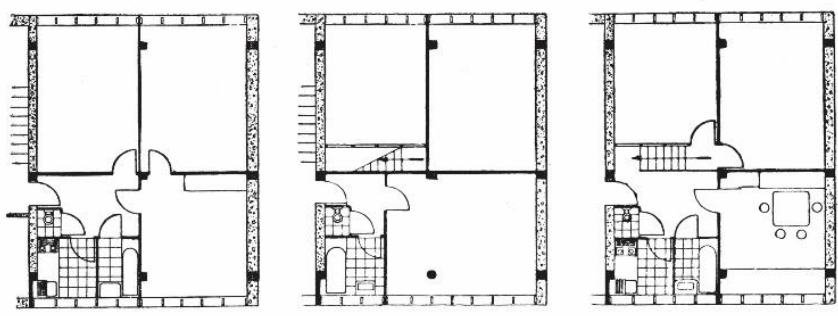

2-F tipi birime ait planlar
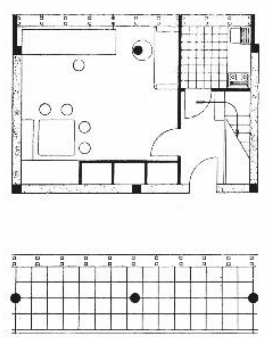

$\mathrm{K}$ tipi birime ait planlar

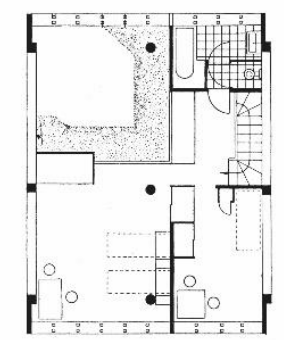

Şekil 11. F, 2-F ve K tipi birimlere ait plan şemaları (solda) (URL-4, 2017) ve yaşama blokunun kesit şeması (sağda) (URL-5, 2015)

Komünal bloka yaşama blokundan üst kotta yer alan bağlantıyla geçilmektedir. Komünal blokta öneri yerleşim planında gösterilen ancak inşa edilmeyen kreş ve ortak yeme- içme mekânı bulunmaktadır. Komünal blokun galerili iç mekânı Barshch ve Vladimirov'un 1929 yılında ortaya koymuş olduğu tasarımda yer verdiği galerili ortak mekânları hatırlatmaktadır. Şekil 12'de Narkomfin Komünal Konutu'nun komünal blokunun galerili iç mekanının restorasyon sonrası hali verilmiştir. Yaşama blokuna 
paralel biçimde konumlandırılan çamaşırhane de tasarımda yer verilen ve yaşama bloku ve komünal bloktan bağımsız olarak inşa edilen tek yapıdır ve diğer yapılarla birlikte restorasyonu yapılmıştır (URL-6, 2021). Şekil 13 'te komünal blokun ve çamaşırhanenin restorasyon öncesindeki hali ve restorasyon sonrası hali verilmiştir.

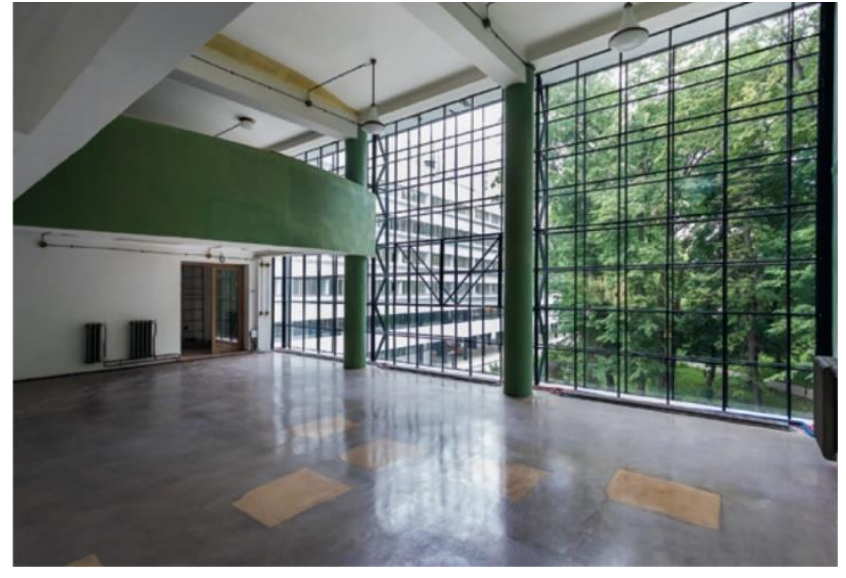

Şekil 12. Restorasyon sonrası komünal blokun galerili iç mekânı (Ginzburg ve Starostina, 2020b) duyuyor musunuz?' sorusuna verilen cevapların grafiği
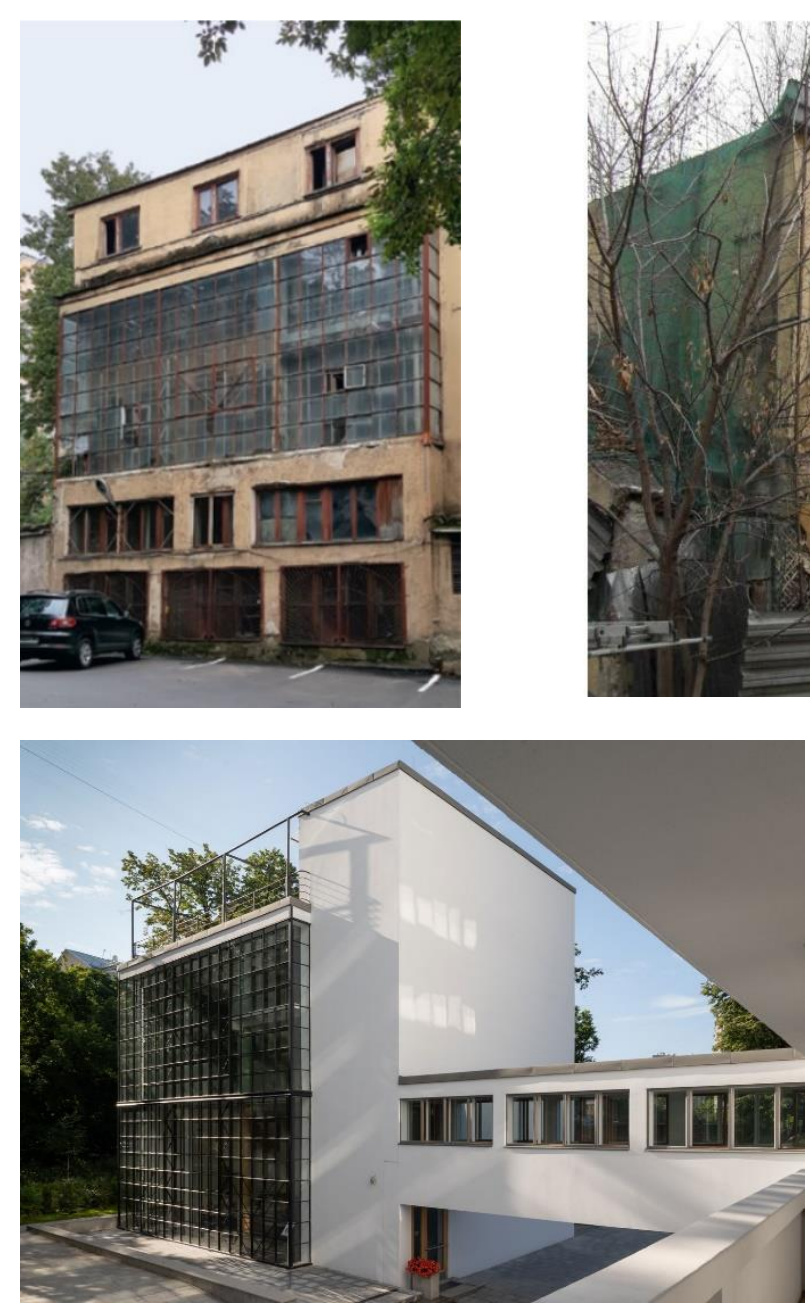
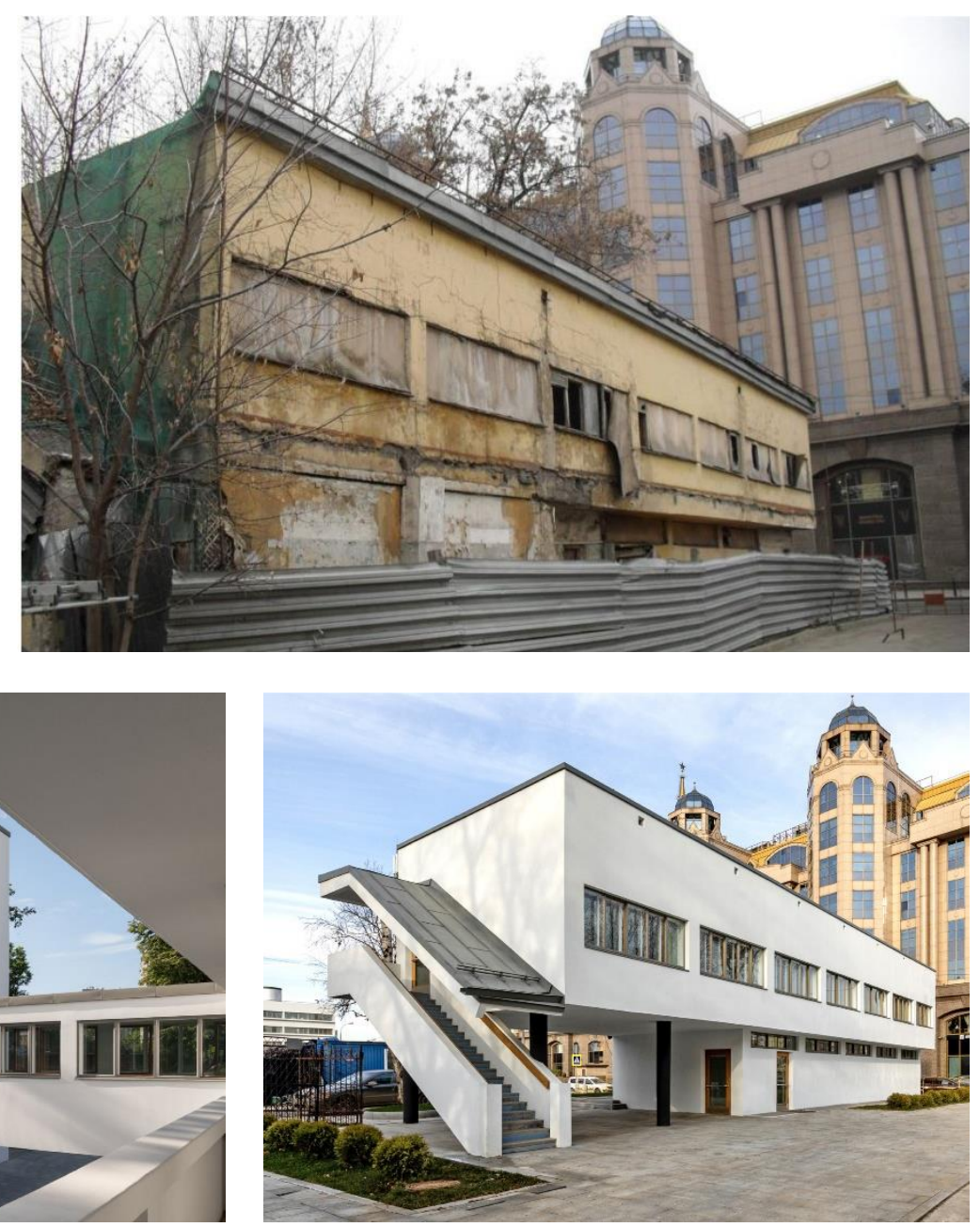

Şekil13. Restorasyon öncesinde komünal blokun (sol üstte) (Ginzburg ve Starostina, 2020b) ve çamaşırhanenin hali (sağ üstte) (URL-7, 2020), restorasyon sonrasında komünal blokun (sol altta) (URL-8, 2020) ve çamaşırhanenin son hali (sağ altta) (URL-9, 2021) 
İnşasının tamamlanmasının ardından değişen Sovyet politikaları doğrultusunda konstrüktivizm ve dolayısıyla onun ürünlerinden biri olan Narkomfin Komünal Konutu "yabancı menşeli" olarak değerlendirilmiştir (URL-10, 2020). Ancak günümüzde Sovyet Konstrüktivizmi ikonu olarak değerlendirilen Narkomfin Komünal Konutu, 2016-2020 yıllları arasında ortaklarından biri olan Moisei Ginzburg'un mimar torunu Aleksey Ginzburg'un olduğu Ginzburg Mimarlık tarafından restore edilmiştir. Restorasyon çalışmalarına 2016-2017 yıllarında belge toplama ile başlanmış, bu aşamada Moisei Ginzburg tarafından ortaya konan çalışmalar, Stroikom bünyesinde üretilen tasarımlar incelenmiştir. Restorasyonun başlangıçtaki ana amacı, yapıları mümkün olduğu kadar inşa edildiği haliyle korumak olarak kabul edilmişse de birçok aşamada yapının ve yapı elemanlarının korunamayacak kadar yıpranmıs olduğu ifade edilmiştir. Bu nedenle korunması mümkün olmayan yapı elemanları, kendi dönemlerinin yöntemleriyle yeniden üretilmiştir. Yeniden üretilen elemanlarla korunan orijinal elemanlar arasında ayrımın yapılabilmesi için görsel farklılıklara dikkat edilmiştir. Fonksiyonel anlamda günümüz intiyaçlarının karşılanması gerektiği düşünüldüğünde Venedik Tüzüğü'nün de dikkate alındığı vurgulanmıştır. Yapının restorasyon öncesi durumu detaylı şekilde belgelenmiş; çizimler üzerinde bozulmalar (sıva dökülmeleri, cephede yer alan betonarme elemanlar üzerinde görülen bozulmalar vb.) işlenmiş, yeniden üretilmesi gereken veya korunması gereken taşıyıcı elemanlar belirlenmiş, kaldırılacak muhdes ekler gösterilmiştir. Modern bir gereklilik sayılabilecek asansörün bu çalışmalar kapsamında yapıya ilave edildiği belirtilmiştir.

\section{SONUÇLAR}

Barınma intiyacı, insanın en temel intiyaçlarındandır. Bu intiyacın giderilmesinde tarih boyunca mimari anlamda farklı çözüm önerileri farklı bağlamlarda geliştirilmiştir. İdeolojik bağlamda çözüm önerileri yerel sorunlara da çözüm olması amacıyla ele alındığında, Sovyet Rusya'da Moisei Ginzburg'un başını çektiği Modern Mimarlar Birliği (OSA)'nin çalışmaları ideolojik anlamda komünal konutun temellerini atmıştır. Bu temeller devlet desteği ile Stroikom bünyesinde yapılan çalışmalarla geliştirilmiş, elde edilen konut tasarımları, Batıdaki çalışmalara benzer şekilde farkı başlıklarda analiz ve optimizasyonlarla iyileştirilmiştir. Bu çalışmaların sonucunda 1928 yılında inşa edilmiş Narkomfin Komünal Konutu önemli yere sahiptir.

Narkomfin Komünal Konutu, kullanıcılarını belirli temel fonksiyonlar dışında (uyuma, kişisel hijyen vb.) ortak mutfaklara, yeme- içme, dinlenme, okuma salonlarına yönlendirmektedir. Çocukların bakımının sağlandığı kreş sayesinde anne olan kullanıcıların iş gücüne katılabilmesi teşvik edilmektedir. Böylelikle komünal yaşama geçişin mimari aracılığıyla sağlanabileceği düşünülmüştür. Ancak bu düşünceler pratikte belirli yönlerden karşılık bulamamıştır. Komünal yaşamın simgesi olarak ifade edilen $\mathrm{F}$ tipi konut biriminin zaman içinde aileler için tasarlanmış $\mathrm{K}$ tipi konut birimine göre daha fazla rağbet göreceği fikri gerçekleşmemiştir. Süreç içinde bireyselliğin artması yerine aile yaşantısının öne çıktığı görülmüştür (Arıtan, 2004).

Konut yapıları, kullanıcılarının sahiplenmesi, yaşam biçimlerine göre düzenlemesi bakımından diğer yapı türlerinden farklı bir yere sahiptir. Her ne kadar mimarlık aracılığıyla gündelik hayatın odağında olan konutun biçimlendirilmesiyle ideolojik fikirlerin toplumda yerleştirilmesi için çalışılsa da bu durumun belirli bir noktaya kadar gerçekleştirilebileceği, Narkomfin Komünal Konutu'nda K tipi konuttan F tipi konuta geçişin sağlanamamasıyla örneklenebilmektedir. Konut mimarisinin aracı olarak kullanılması yoluyla toplumun yeniden inşasında aile yapısında bireyselliğin ön plana çıkarılması amacı hedeflenen başarıya ulaşamamıştır.

Restorasyon çalışmaları esnasında insanların yaşama birimlerini meraktan veya tarihi anlamını bildikleri için görmeye geldikleri belirtilmiştir. Bu ziyaretlerde döneminin şartlarıyla ortaya konan Narkomfin Komünal Konutu'nun restorasyonla birlikte günümüz ihtiyaçlarını da karşılayabileceği yorumlanmıştır (Ginzburg ve Starostina, 2020c). İnşa edildiği dönemde her ne kadar ideolojik bağlamla ilişkilendirilse de yıllar sonra ideolojik bağlamın ortadan kalkması yapıyı etkilememiştir. Bu durum, yapının ideolojik bağlamla birlikte temelde insan intiyaçlarını ele alması olarak ifade edilebilir.

\section{KAYNAKLAR}

Andrusz, G. D. (1990). Housing and Urban Development in the USSR. Macmillan, $371 \mathrm{p}$.

Arıtan, Ö. (2004). Kapitalist/ Sosyalist Modernleşme Modellerinin Erken Cumhuriyet Dönemi Mimarlığının Biçimlenişine Etkileri- Sümerbank KIT Yerleşkeleri Üzerinden Yeni Bir Anlamlandırma Denemesi. Doktora Tezi, Dokuz Eylül Üniversitesi Fen Bilimleri Enstitüsü Bina Bilgisi Ana Bilim Dalı, İzmir, $459 \mathrm{~s}$.

Buchli, V. (1998). Moisei Ginzburg's Narkomfin Communal House in Moscow: Contesting the Social and Material World. Journal of the Society of Architectural Historians, 57: 160181.

Ginzburg, A., Starostina, A. (2020a). Vladimir Ginzburg and the first steps toward the restoration of the Narkomfin Building. 1985-2015. In: The Narkomfin Building, Restoration 2016-2020, Alexey Ginzburg (auth.), Publication of Department of Cultural Heritage of the City of Moscow, 32-36. https://www.mos.ru/dkn/documents/view/248242220/ (Erişim Tarihi: 25.03.2021) 
Ginzburg, A., Starostina, A. (2020b). The Restoration Project and Its Realization. 2016-2020. In: The Narkomfin Building, Restoration 2016-2020, Alexey Ginzburg (auth.), Publication of Department of Cultural Heritage of the City of Moscow, 37-125. https://www.mos.ru/dkn/documents/view/248242220/ (Erişim Tarihi: 25.03.2021)

Ginzburg, A., Starostina, A. (2020c). The new life of the Narkomfin building: the residential function 90 yearson. In: The Narkomfin Building, Restoration 2016-2020, Alexey Ginzburg (auth.), Publication of Department of Cultural Heritage of the City of Moscow, 37-125. https://www.mos.ru/dkn/documents/view/248242220/ (Erişim Tarihi: 25.03.2021)

Guillén, M., F. (2008). The Taylorized Beauty of the Mechanical: Scientific Management and the Rise of Modernist Architecture. Princeton University Press, $208 \mathrm{p}$.

Kazus, I. A. (2020). The Narkomfin building as a manifesto fort he modern way of life. In: The Narkomfin Building, Restoration 2016-2020, Alexey Ginzburg (auth.) Publication of Department of Cultural Heritage of the City of Moscow, 1231. https://www.mos.ru/dkn/documents/view/248242220/ (Erişim Tarihi: 25.03.2021)

Khmelnitsky, D. (2016). Moisej Ginzburg and Soviet Residential Architecture. In: Narkomfin Moisej J. Ginzburg, Ignatij F. Milinis, Danilo Udovički- Selb (ed.), Wasmuth, 192 p.

Sherwood, R. (1981). Modern Housing Prototypes. Harvard University Press, $184 \mathrm{p}$

Teige, K. (2002). The Minimum Dwelling. Translated by Eric Dluhosch, MIT Press, $432 \mathrm{p}$.

URL-1 (2015). https://monoskop.org/images/3/39/Sovremennaya_arkhitektura_1927_4-5.pdf (Erişim Tarihi: 30.12.2020)
URL-2 (2020). http://inrussia.com/tour-the-house-of-narkomfin (Erişim Tarihi: 30.12 .2020$)$

URL-3 (2012). https://laboratoireurbanismeinsurrectionnel.blogspot.com/2012/04/urss-habitat-et-dom-kommuny.html (Erişim Tarihi: 16.04.2021)

URL-4 (2017). https://www.architectural-review.com/essays/making-sense-of-narkomfin (Erişim Tarihi: 17.04.2021)

URL-5

(2015)

https://i.pinimg.com/564x/9d/92/e8/9d92e88ad6da4661e08d5c7436 7abcbf.jpg (Erişim Tarihi: 30.12.2020)

URL-6 (2021). https://ginzburg-architects.com/en/projects/restoration/zdanie-prachechnoj-narkomifina (Erişim Tarihi: 17.04.2021)

URL-7 (2020). https://ginzburg-architects.com/media/projects/Proj1/Prachechnaya_narkomfina_before_restoration_2048x1500.jpg (Erişim Tarihi: 05.06.2021)

URL-8 (2020). https://ginzburg-architects.com/media/projects/Narkomfin/Ot_14_01_2020/_YPL4233.jpg (Erişim Tarihi: 17.04.2021)

URL-9 (2021). https://ginzburg-architects.com/media/projects/prachechnaya-narkomfina.jpg (Erişim Tarihi: 17.04.2021)

URL-10 (2020). https://www.archdaily.com/947148/the-winding-saga-of-the-restoration-of-the narkomfin-an-icon-ofsoviet-constructivism (Erişim Tarihi: 24.01.2021)

Vega, D. M. (2020). Housing and Revolution: From the DomKommuna to the Transitional Type of Experimental House (1926-30). Architectural Histories, 8(1): 2; DOI: http://doi.org/10.5334/ah.264 